\title{
GIS-Based Evaluation on the Eco-Demonstration Construction in China
}

\author{
Lingxian Zhang, Juncheng Ma, Daoliang Li, and Zetian Fu* \\ College of Information \& Electrical Engineering, China Agricultural University, \\ P.O. Box 209, 17 Qinghua East Road, Haidian District, Beijing, China \\ zlx131@163.com, fzt@cau.edu.cn
}

\begin{abstract}
The ecological construction for demonstration area is an idealized model for the establishment of rural sustainable development in the county-scale. This paper presents a GIS-based evaluation system of ecological construction for demonstration area. It includes an index system with the 4 secondary indices and 24 factor indices, and a method of ecological construction for demonstration area utilizing multi-attribute decision models of AHPCI method for comprehensive performance assessment. Taking Xinyang city of Henan province in China as a case study, the comprehensive assessment result were found to be coincident with practical situation, so it proves that the GIS-based evaluation system was fit for county-level ecological construction assessment for demonstration area as a beneficial reference framework elsewhere.
\end{abstract}

Keywords: Evaluation system, Eco-demonstration construction, AHPCI, Sustainable development.

\section{Introduction}

Since United Nations Conference on Environment and Development (UNCED) in 1990s, the sustainable development concept has gradually been accepted all over the world with respect to almost all aspects of human development [1]. The ecodemonstration area is regarded as an important way to maintain regional sustainable development in many countries. The ecological construction for demonstration area is an idealized model for the establishment of rural sustainable development in the county-scale. Eco-demonstration area is a compound ecosystem of society, economy and nature, which is relatively independent and exoteric [2]. The eco-demonstration concept lies close to the UN Millennium Project [3] and aims at making a contribution to this programme. Eco-demonstration construction refers to the application of ecological principles to the development of human ecosystems in order to achieve sustainability. It consists of three components: ecological engineering, ecological institutional reestablishment and ecological cultural remolding.

Since 1980, a vigorous campaign for the ecological construction for demonstration area has appeared in China, and many eco-polis, eco-counties, eco-villages as well as eco-families had sprung up all over the country [4]. In 1996, the Ministry of

* Corresponding author. Tel.: +86010 62736323; Fax: +86 01062737741 . 
Environmental Protection of China(MEPC) carried out the activities of the national creation of eco-demonstration area, and a lot of eco-demonstration areas had been created in our country, as not only promoted coordination of economy, society and environmental protection in pilot region but also have positive effect on surrounding areas [5]. The evaluation of sustainable development for eco-demonstration area is the base of perfecting the sustainable development theory for eco-demonstration area and guiding its construction [6].

To promote the benign development of eco-demonstration area construction, this paper promoted an evaluation index system of eco-demonstration area construction based on criterion for eco-demonstration area construction issued by MEPC, and developed a GIS-based assessment model utilizing the Analytical Hierarchy Process (AHP) and Competitiveness Index (AHPCI) method.

\section{Evaluation Methodology for Intra-county Eco-Demonstration Construction}

\subsection{Evaluation Index System of Intra-county Eco-Demonstration Construction}

Taking the criterion of the national creation of eco-demonstration area and goal of eco-demonstration construction into account, the paper presented a set of quantitative and hierarchical index system with the 4 secondary indices, and 24 factor indices by integrating the assessment goal and the standards of eco-demonstration construction announced by MEPC according to the design principles and requirements of the index system (Table 1).

Table 1. Index systems and its standard for the intra-county eco-demonstration construction

\begin{tabular}{|c|c|c|c|c|c|c|}
\hline \multirow{2}{*}{$\begin{array}{l}\text { Primary } \\
\text { index }\end{array}$} & \multirow{2}{*}{ Second index } & \multirow{2}{*}{ Third index } & \multicolumn{2}{|l|}{ Fourth index } & \multicolumn{2}{|c|}{ Reference value } \\
\hline & & & Name & Code & $\begin{array}{l}\text { Upper } \\
\text { limit }\end{array}$ & $\begin{array}{l}\text { Lower } \\
\text { limit }\end{array}$ \\
\hline \multirow{7}{*}{ 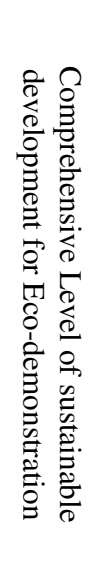 } & \multirow{7}{*}{$\begin{array}{c}\text { Economic } \\
\text { development }\end{array}$} & \multirow{3}{*}{$\begin{array}{l}\text { National } \\
\text { income }\end{array}$} & GDP per capita & $\mathrm{Q}_{11}$ & & \\
\hline & & & $\begin{array}{l}\text { Disposable income of } \\
\text { urban residents }\end{array}$ & $\mathrm{Q}_{12}$ & & \\
\hline & & & $\begin{array}{l}\text { Per capita annual net } \\
\text { income of peasantry }\end{array}$ & $\mathrm{Q}_{13}$ & $>4000$ & 1600 \\
\hline & & \multirow{4}{*}{$\begin{array}{l}\text { Economic } \\
\text { structure }\end{array}$} & $\begin{array}{l}\text { Unit GDP energy } \\
\text { consumption(ton/ten } \\
\text { thousand) }\end{array}$ & $\mathrm{Q}_{21}$ & $1.3-1.4$ & $1.5-1.6$ \\
\hline & & & $\begin{array}{l}\text { Unit GDP water } \\
\text { consumption } \\
\text { (cubic meter/ten } \\
\text { thousand) }\end{array}$ & $\mathrm{Q}_{22}$ & $<200$ & $<600$ \\
\hline & & & $\begin{array}{l}\text { Proportion of } \\
\text { investment in } \\
\text { environment protection } \\
\text { in GDP }(\%)\end{array}$ & $\mathrm{Q}_{23}$ & 1 & 1.2 \\
\hline & & & $\begin{array}{l}\text { Water productivity } \\
\text { (kilogram/cubic meter) }\end{array}$ & $\mathrm{Q}_{24}$ & $>1.5$ & 0.9 \\
\hline
\end{tabular}


Table 1. (continued)

\begin{tabular}{|c|c|c|c|c|c|}
\hline \multirow{6}{*}{$\begin{array}{c}\text { Social } \\
\text { progress }\end{array}$} & \multirow{4}{*}{ Life quality } & $\begin{array}{l}\text { The natural population } \\
\text { growth rate }(\%)\end{array}$ & $\mathrm{Q}_{31}$ & \multicolumn{2}{|c|}{ Local criterion } \\
\hline & & $\begin{array}{l}\text { Eligibility rate of urban } \\
\text { drinking water }(\%)\end{array}$ & $\mathrm{Q}_{32}$ & $\geq 90$ & $\geq 60$ \\
\hline & & $\begin{array}{l}\text { City gasification } \\
\text { efficiency }\end{array}$ & $\mathrm{Q}_{33}$ & $>90$ & $>35$ \\
\hline & & $\begin{array}{l}\text { Coverage rate of } \\
\text { sanitary toilets in rural } \\
\text { areas }(\%)\end{array}$ & $\mathrm{Q}_{34}$ & $>70$ & $>35$ \\
\hline & \multirow{2}{*}{ Harmony } & Urbanization (\%) & $\mathrm{Q}_{41}$ & & \\
\hline & & GDP per capita & $\mathrm{Q}_{42}$ & & \\
\hline \multirow{7}{*}{$\begin{array}{c}\text { Ecological } \\
\text { construction }\end{array}$} & \multirow{3}{*}{$\begin{array}{l}\text { Resource } \\
\text { utilization }\end{array}$} & $\begin{array}{l}\text { Disposable income of } \\
\text { urban residents }\end{array}$ & $\mathrm{Q}_{51}$ & \multicolumn{2}{|c|}{ National criterion } \\
\hline & & $\begin{array}{l}\text { Per capita annual net } \\
\text { income of peasantry }\end{array}$ & $\mathrm{Q}_{52}$ & $>10$ & $>7$ \\
\hline & & $\begin{array}{l}\text { Unit GDP energy } \\
\text { consumption(ton/ten } \\
\text { thousand) }\end{array}$ & $\mathrm{Q}_{53}$ & 100 & $>80$ \\
\hline & \multirow{4}{*}{$\begin{array}{c}\text { Environment } \\
\text { protection }\end{array}$} & $\begin{array}{l}\text { Unit GDP water } \\
\text { consumption }\left(\mathrm{m}^{3} / \text { ten }\right. \\
\text { thousand })\end{array}$ & $\mathrm{Q}_{61}$ & $>10$ & $>10$ \\
\hline & & $\begin{array}{l}\text { Proportion of } \\
\text { investment in } \\
\text { environment protection } \\
\text { in GDP }(\%)\end{array}$ & $\mathrm{Q}_{62}$ & $>90$ & $>80$ \\
\hline & & $\begin{array}{l}\text { Water productivity } \\
\left(\mathrm{kg} / \mathrm{m}^{3}\right)^{2}\end{array}$ & $\mathrm{Q}_{63}$ & $>80$ & $>60$ \\
\hline & & $\begin{array}{l}\text { The natural population } \\
\text { growth rate }(\%)\end{array}$ & $\mathrm{Q}_{64}$ & $>50$ & $>30$ \\
\hline \multirow{4}{*}{\multicolumn{2}{|c|}{ Environment protection }} & $\begin{array}{l}\text { Comprehensive } \\
\text { utilization of straw }\end{array}$ & $\mathrm{Q}_{71}$ & $>90$ & $>70$ \\
\hline & & $\begin{array}{l}\text { Manure disposal rate } \\
(\%)\end{array}$ & $\mathrm{Q}_{72}$ & 100 & 80 \\
\hline & & $\begin{array}{l}\text { Amount of fertilizer } \\
\text { application (equivalent } \\
\text { pure, kg/ha) }\end{array}$ & $\mathrm{Q}_{73}$ & $<280$ & $<280$ \\
\hline & & $\begin{array}{l}\text { Amount of pesticide } \\
\text { application (equivalent } \\
\text { pure, } \mathrm{kg} / \mathrm{ha} \text { ) }\end{array}$ & $\mathrm{Q}_{74}$ & $<3.0$ & $<3.0$ \\
\hline
\end{tabular}


In the index system, the comprehensive level of sustainable development for ecodemonstration areas is regarded as the general goal. In order to realize the regional sustainable development, the basis of resource and environment that support the development of social and economy is needed. Therefore, this paper divided the general goal into 4 sub-goals of economic development, social progress, ecological construction and environmental protection, which were further divided into the third level indices of national income, economic structure, quality of life, harmony, resource utilization, environmental management and protection. According to the requirements and principles, the general goal was divided into 24 indices.

\subsection{Assessment Model of the Intra-county Eco-Demonstration Construction}

Constructing the hierarchical structural model. Following AHP, the level of sustainable development for eco-demonstration area is divided into three hierarchical structural levels from the bottom to the top. In the top is the general goal of the hierarchical structure, namely the overall objective layer with only one key element for the comprehensive level of sustainable development for eco-demonstration. The intermediate level is the criterion layer with several intermediate elements, such as economic development, social progress, ecological construction and environmental protection. The bottom, namely influence factors layer, is composed of various kinds of factors in evaluation system. There exist specific logic relationships between neighbor layers. The hierarchical structural model for evaluating the ecodemonstration construction was showed in Fig.1.

Presenting the comparison matrix by layers. The comparison matrix below provides a measure of the weight factors for decision making, which denotes the relative importance of the element of each layer shown in the hierarchical structural model. Often from top to bottom, the comparison matrix could be established with one element of the above layer pairing and comparing with all the elements of the neighboring below layer according to the relationship between the elements or the layers. Between layer A and B showed in Fig.1, the comparison matrix of A-B layer can be established (Table 2), whose elements are evaluated using a 9-point scale.

The comparison matrix is a square matrix as $\mathrm{A}=\left(\mathrm{B}_{\mathrm{ij}}\right)_{\mathrm{n} \times \mathrm{n}}$, and:

$$
\mathrm{B}_{\mathrm{ij}}>0 ; \quad \mathrm{B}_{\mathrm{ij}}=1 / \mathrm{B}_{\mathrm{ji}} ; \quad \mathrm{B}_{\mathrm{ii}}=\mathrm{B}_{\mathrm{jj}}=1
$$

Where $B_{i j}$ is the pairing comparison of element $i$ with element $j$ in the B layer of the A-B comparison matrix.

Similarly, the comparison matrix of B-C and C-Q layers can be obtained in the same way used in forming the comparison matrix of A-B layers. Data on paired comparison matrices were collected from reviewers. Scores of $\mathrm{B}_{\mathrm{ij}}$ were estimated on the average by experts. The participating decision makers provided paired comparisons for each level of the hierarchy in order to obtain the weight factors of each element on that level, and with respect to one element in the next higher level [7]. 


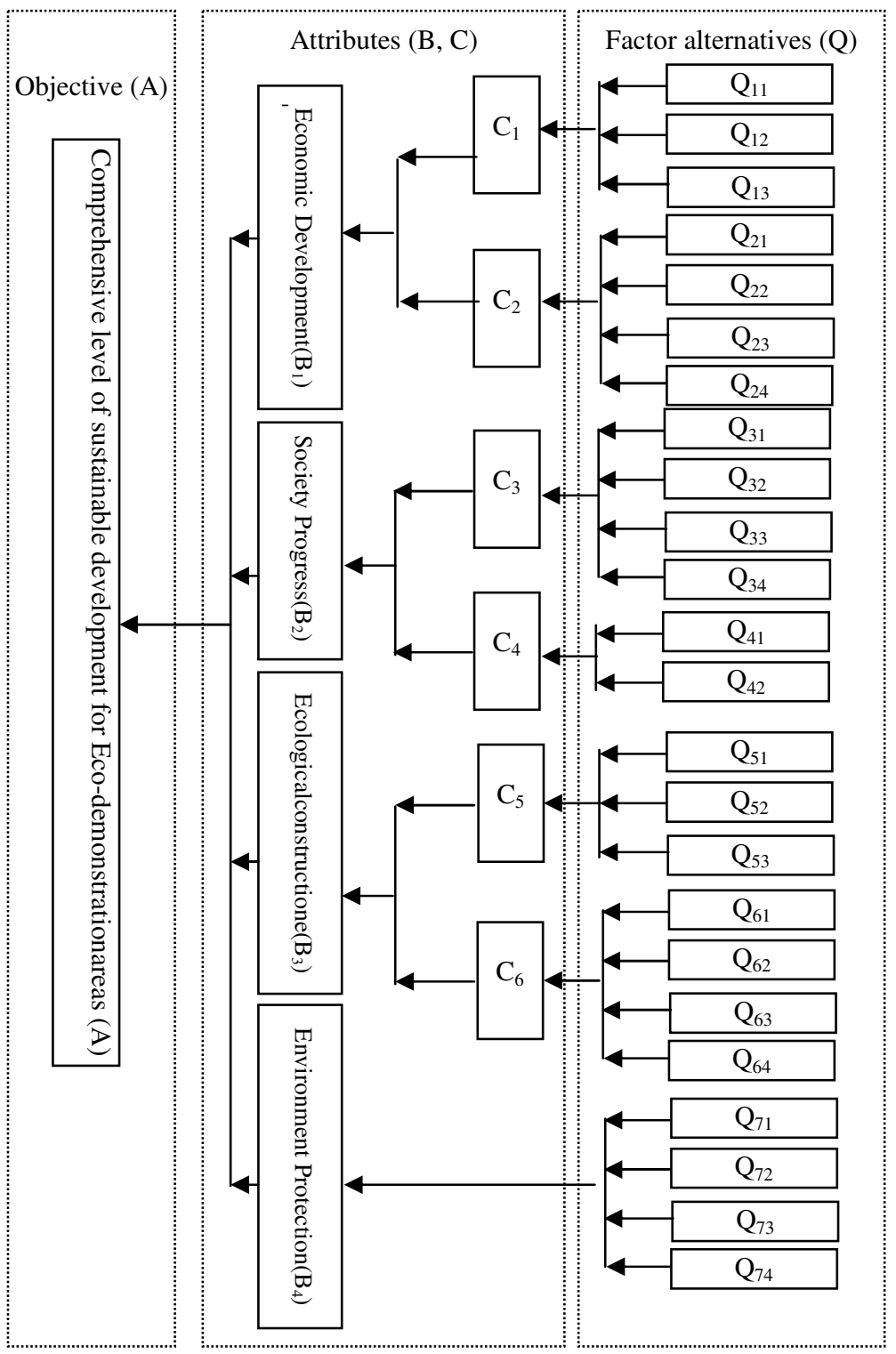

Fig. 1. Hierarchical structural model for evaluating the eco-demonstration construction 
Table 2. A-B comparison matrix

\begin{tabular}{lllll}
\hline$A$ & $B_{1}$ & $B_{2}$ & $B_{3}$ & $B_{4}$ \\
\hline$B_{1}$ & $B_{11}$ & $B_{12}$ & $\mathrm{~B}_{13}$ & $\mathrm{~B}_{14}$ \\
$B_{2}$ & $\mathrm{~B}_{21}$ & $\mathrm{~B}_{22}$ & $\mathrm{~B}_{23}$ & $\mathrm{~B}_{24}$ \\
$B_{3}$ & $\mathrm{~B}_{31}$ & $\mathrm{~B}_{32}$ & $\mathrm{~B}_{33}$ & $\mathrm{~B}_{34}$ \\
$B_{4}$ & $\mathrm{~B}_{41}$ & $\mathrm{~B}_{42}$ & $\mathrm{~B}_{43}$ & $\mathrm{~B}_{44}$ \\
\hline
\end{tabular}

\subsection{Calculation of Comprehensive Level of Sustainable Development for Eco-Demonstration}

In ecological evaluation for eco-demonstration construction based on rural sustainable development, we adopt the evaluation standard of the comprehensive level of sustainable development (Table 1). In order to better carry out analysis and comparison, this paper has adopted a methodology of the comprehensive evaluation index to calculate the weight of every index to comprehensive level of sustainable development for an eco-demonstration area. Each index is translated into a dimensionless index score such as GDP per capita, amount of fertilizer application etc.; then weighted in order produce a measure of the comprehensive level of sustainable development for the eco-demonstration area.

The specific methods of evaluation are as follows:

a) For the positive index, let

$$
\mathbf{Q}_{i j}=\frac{\boldsymbol{x}_{i j}-\boldsymbol{x}_{\min (\mathrm{j})}}{\boldsymbol{x}_{\max (\mathrm{j})}-\boldsymbol{x}_{\min (\mathrm{j})}} \quad x_{\min (j)}<x_{i j}<x_{\max (j)}
$$

a) For the negative index, let

$$
\mathbf{Q}_{i j}=\frac{\boldsymbol{x}_{\max (j)}-\boldsymbol{x}_{i j}}{\boldsymbol{x}_{\max (j)}-\boldsymbol{x}_{\min (j)}} \quad x_{\min (j)}<x_{i j}<x_{\max (j)}
$$

Where $\mathrm{j}$ is a sequence number for evaluation subordinate systems, $\mathrm{i}$ is a serial number of indices in a subordinate system; $x_{i j}$ is the original values of indices in a hierarchy of $\mathrm{i}$ and $\mathrm{j}$, respectively; $\mathbf{Q}_{i j}$ is only the standard transformation values of $x_{i j} ; x_{\min (j)}, x_{\max (j)}$ are lower limit or upper limit values of indices in a evaluation subordinate system, respectively.

Calculating by weight in term and layer from the beginning of the specific index, we obtained the overall value of the comprehensive level of sustainable development. This can be expressed as follows:

$$
\mathbf{C I}=\sum_{\mathrm{i}=1}^{\mathrm{n}} \mathbf{W}_{\mathrm{i}}\left(\sum_{\mathrm{j}=1}^{\mathrm{m}} \mathbf{W}_{\mathrm{ij}} \mathbf{Q}_{\mathrm{ij}}\right)
$$

Where CI is competitiveness index, representing the comprehensive level of sustainable development for eco-demonstration areas; $\mathrm{n}$ is the number the component factors of the comprehensive level of sustainable development for eco-demonstration 
areas, here $\mathrm{n}$ for 4 ; $\mathrm{m}$ represents sub-factor in number $\mathrm{i}$ component factor of the comprehensive level of sustainable development for eco-demonstration areas; $\mathbf{Q}_{\mathbf{i j}}$ is the standardized value of number $\mathrm{j}$ sub-factor of number $\mathrm{i}$ component factor; $\mathrm{W}_{\mathrm{ij}}$ is the weight of number $\mathrm{j}$ sub-factor of number $\mathrm{i}$ component factor.

By taking various statistical yearbooks, bulletins and other relative data, and national and international corresponding index standards into account, we designed a four-stage classification standard with the critical value and values of upper and lower limit of the CI of the comprehensive level of sustainable development for ecodemonstration areas (Table 3).

Table 3. Classification standard of the comprehensive level evaluation [8]

\begin{tabular}{ccc}
\hline Level & Critical value & $\begin{array}{c}\text { Qualitative evaluation of } \\
\text { comprehensive level of } \\
\text { sustainable development }\end{array}$ \\
\hline I & $>0.75$ & Very good \\
II & $0.50-0.75$ & Better \\
III & $0.25-0.49$ & General \\
IV & $<0.25$ & Poor \\
\hline
\end{tabular}

\subsection{Design of GIS-Based Evaluation System}

According to the evaluation algorithm of the comprehensive level of sustainable development for eco-demonstration areas aforementioned, this paper put forward a GIS-based evaluation system of ecological construction for demonstration area, which was designed three modules, including GIS operating, thematic evaluation and auxiliary module, in virtue of the geographic information system technology (Fig.2).

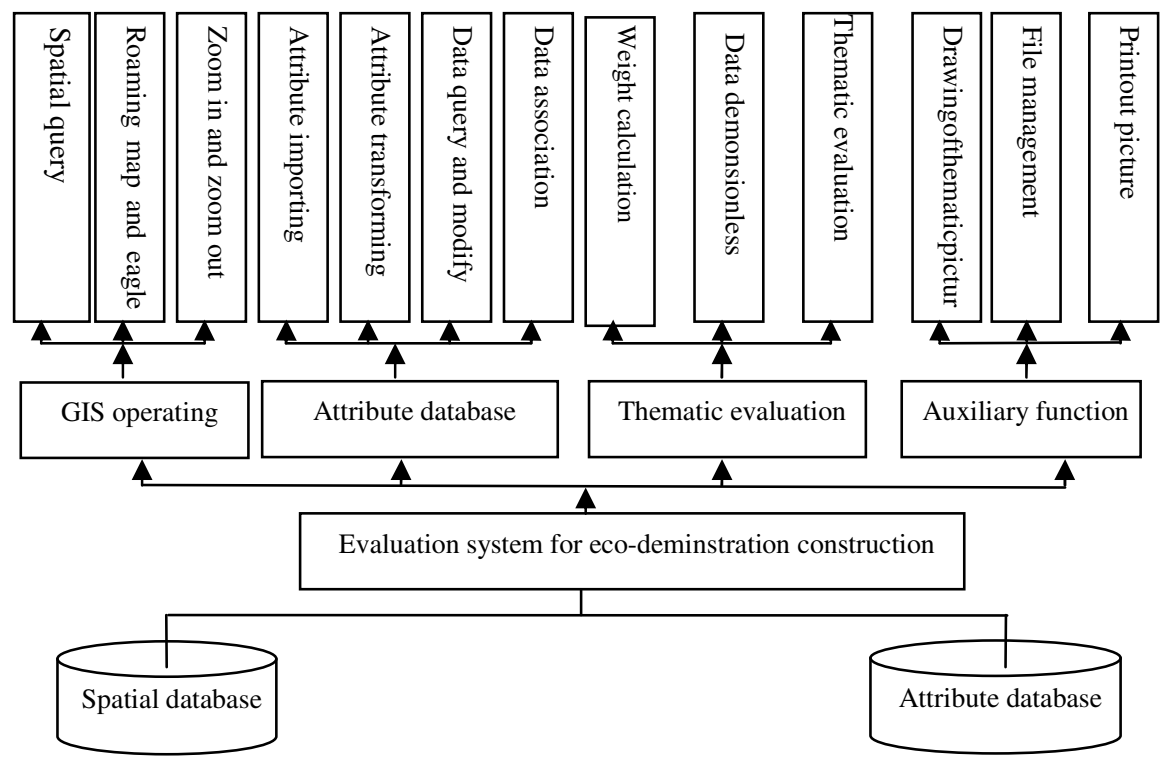

Fig. 2. Function frame of GIS-based evaluation system 


\section{Results and Discussion}

\subsection{General Situation of Study Area}

This paper took evaluation of the sustainable development level for ecodemonstration area at Xinyang city of Henan province in China as an example to test the effectiveness of the AHPCI method.

Xinyang city is located in south part of Henan province, P.R China. It consists of 8 counties and 2 districts, with the population of 7.8 million, the total area of 18000 $\mathrm{km}^{2}$. Only one of Xinyang city, Luoshan county, was identified as the national ecodemonstration area in 2004. By comparing CI of the 9 counties at Xinyang city (two districts as one), we could conveniently analyze the construction performance of ecodemonstration area at Luoshan county, and provided a beneficial reference framework for the eco-demonstration construction elsewhere.

\subsection{Weight Calculation and Consistency Test}

From Fig.1, the comparison matrix of A-B layer would be considered consistent (and accepted) with a $\mathrm{CR}$ (consistency ratio) lower than 0.1. Similarly, we could obtain the weight of the evaluation attribute layer $C_{1}-C_{2}$ to $B_{1}, C_{3}-C_{4}$ to $B_{2}, C_{5}-C_{6}$ to $B_{3}$; and the weight of the evaluation index layer $Q_{11}-Q_{13}$ to $C_{1}, Q_{21}-Q_{24}$ to $C_{2}, Q_{31}-Q_{34}$ to $C_{3}, Q_{41}-Q_{42}$ to $\mathrm{C}_{4}, \mathrm{Q}_{51}-\mathrm{Q}_{53}$ to $\mathrm{C}_{5}, \mathrm{Q}_{61}-\mathrm{Q}_{64}$ to $\mathrm{C}_{6}, \mathrm{Q}_{71}-\mathrm{Q}_{74}$ to $\mathrm{B}_{4}$ (wholly passed the consistency test, and accepted) (Tables 4 and 5).

Table 4. Single ranking of the assessment factors

\begin{tabular}{cccllc}
\hline Index & $\mathrm{B}_{1}$ & $\mathrm{~B}_{2}$ & $\mathrm{~B}_{3}$ & $\mathrm{~B}_{4}$ & $\begin{array}{l}\text { Single } \\
\text { ranking }\end{array}$ \\
\cline { 2 - 5 } & 0.455 & 0.263 & 0.141 & 0.141 & 0.091 \\
\hline $\mathrm{C}_{1}$ & 0.200 & & & & 0.364 \\
$\mathrm{C}_{2}$ & 0.800 & & & & 0.197 \\
$\mathrm{C}_{3}$ & & 0.750 & & & 0.066 \\
$\mathrm{C}_{4}$ & & 0.250 & & 0.035 \\
$\mathrm{C}_{5}$ & & & 0.250 & 0.106 \\
$\mathrm{C}_{6}$ & & & 0.750 & \\
\hline
\end{tabular}

From Table 4, we could find that in the second layer, economic development had the maximum weight (0.455), while in the third layer, $\mathrm{C}_{2}$ (economic structure) had the maximum weight (0.364).

Table 5 showed obviously the weight of 24 evaluation indices of the fourth layer to the general objective of the comprehensive level of sustainable development for ecodemonstration, of which unit GDP energy consumption (0.105) reached the largest influence and the second was the proportion of poor people $(0.098)$, while the least influence was obtained by tourist district environmental compliance rate $(0.004)$. 
Table 5. Total ranking of the factors

\begin{tabular}{|c|c|c|c|c|c|c|c|c|}
\hline \multirow{2}{*}{ Index } & $\mathrm{C}_{1}$ & $\mathrm{C}_{2}$ & $\mathrm{C}_{3}$ & $\mathrm{C}_{4}$ & $\mathrm{C}_{5}$ & $\mathrm{C}_{6}$ & $\mathrm{~B}_{4}$ & \multirow{2}{*}{$\begin{array}{l}\text { Total } \\
\text { ranking }\end{array}$} \\
\hline & 0.091 & 0.364 & 0.197 & 0.066 & 0.035 & 0.106 & 0.141 & \\
\hline $\mathrm{Q}_{11}$ & 0.539 & & & & & & & 0.049 \\
\hline $\mathrm{Q}_{12}$ & 0.164 & & & & & & & 0.015 \\
\hline $\mathrm{Q}_{13}$ & 0.297 & & & & & & & 0.027 \\
\hline $\mathrm{Q}_{21}$ & & 0.445 & & & & & & 0.105 \\
\hline $\mathrm{Q}_{22}$ & & 0.283 & & & & & & 0.092 \\
\hline $\mathrm{Q}_{23}$ & & 0.165 & & & & & & 0.060 \\
\hline $\mathrm{Q}_{24}$ & & 0.107 & & & & & & 0.039 \\
\hline $\mathrm{Q}_{31}$ & & & 0.589 & & & & & 0.086 \\
\hline $\mathrm{Q}_{32}$ & & & 0.193 & & & & & 0.070 \\
\hline $\mathrm{Q}_{33}$ & & & 0.149 & & & & & 0.034 \\
\hline $\mathrm{Q}_{34}$ & & & 0.069 & & & & & 0.014 \\
\hline $\mathrm{Q}_{41}$ & & & & 0.250 & & & & 0.049 \\
\hline $\mathrm{Q}_{42}$ & & & & 0.750 & & & & 0.098 \\
\hline $\mathrm{Q}_{51}$ & & & & & 0.608 & & & 0.021 \\
\hline $\mathrm{Q}_{52}$ & & & & & 0.272 & & & 0.010 \\
\hline $\mathrm{Q}_{53}$ & & & & & 0.12 & & & 0.004 \\
\hline $\mathrm{Q}_{61}$ & & & & & & 0.542 & & 0.037 \\
\hline $\mathrm{Q}_{62}$ & & & & & & 0.233 & & 0.025 \\
\hline $\mathrm{Q}_{63}$ & & & & & & 0.14 & & 0.015 \\
\hline $\mathrm{Q}_{64}$ & & & & & & 0.085 & & 0.009 \\
\hline $\mathrm{Q}_{71}$ & & & & & & & 0.081 & 0.011 \\
\hline $\mathrm{Q}_{72}$ & & & & & & & 0.428 & 0.060 \\
\hline $\mathrm{Q}_{73}$ & & & & & & & 0.301 & 0.042 \\
\hline $\mathrm{Q}_{74}$ & & & & & & & 0.189 & 0.027 \\
\hline
\end{tabular}

\subsection{Intra-county Comprehensive Level of Sustainable Development for Eco-Demonstration}

Fig. 3 and Fig.4 showed the intra-county comprehensive level of sustainable development for eco-demonstration at Xinyang. Xinyang district gets the maximum (0.8757), and

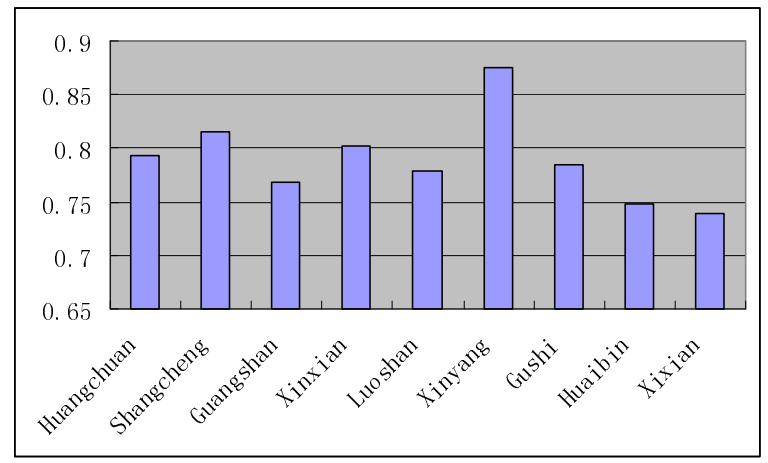

Fig. 3. Intra-county comprehensive level at Xinyang 


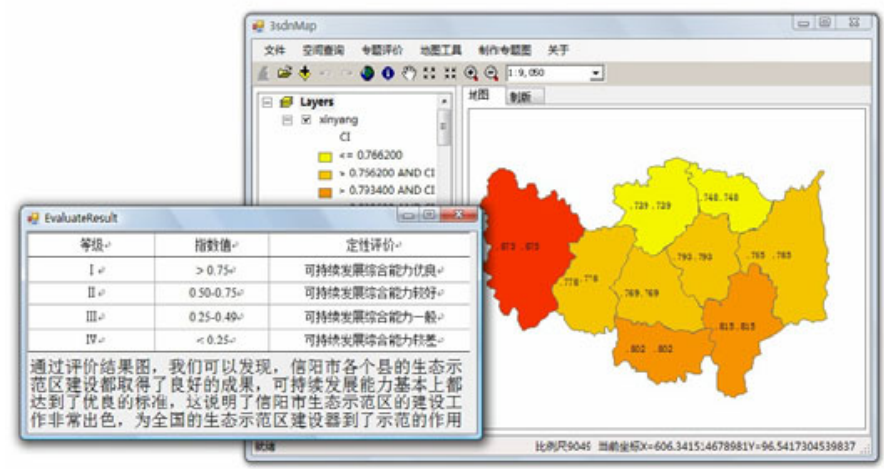

Fig. 4. Thematic evaluation intra-county comprehensive level at Xinyang

Shangcheng ranks the second (0.8149) followed by Xinxian (0.8024), Huangchuan (0.7928), Gushi (0.7846), Luoshan (0.778), Guangshan (0.769), and Xixian (0.7388, minimum). The comprehensive level of Huangchuan, Shangcheng, Guangshan, Xinxian, Luoshan, Xinyang and Gushi are at the level I of the classification standard while Huaibin and Xixian reach at the level II, as is found to be coincident with practical situation.

\section{Conclusion}

Analyzing the literature and combining with the reality, this paper sets 24 evaluation indices according to the principles of evaluation and conditions specified, and establishes the evaluation system of eco-demonstration construction by the AHPCI method as well as develops an evaluation system of intra-county eco-demonstration construction.

The results show that the model of evaluation system of eco-demonstration area reflects the comprehensive level of the 9 counties in Xinyang city and corresponds with the reality, which offers the basis to construction of eco-demonstration sustainable development and contributes to the construction of national ecodemonstration.

The evaluation system of eco-demonstration sustainable development is proved to be reliable, which presents a tool for the evaluation of eco-demonstration sustainable development.

Acknowledgement. Thanks are due to National Science \& Technology Support Program (2008BAB38B06) for financial support.

\section{References}

1. Liang, B.P., Huang, F., Chen, B., Li, H.J.: Comprehensive Evaluation of the Sustainable Development of an Ecological Demonstration District. Bulletin of Soil and Water Conservation 24(1), 74-78 (2004) (in Chinese) 
2. Yang, C.F.: Building High Quality Ecological Demonstration Areas. Environmental Protection 1, 16-19 (2000) (in Chinese)

3. UN Millennium Project: Investing in Development: A Practical Plan to Achieve the Millennium Development Goals. Earthscan, London (2005)

4. Hu, D., Wang, R.S.: Exploring eco-construction for local sustainability: An eco-village case study in China. Ecological Engineering 11, 167-176 (1998) (in Chinese)

5. Yan, H., Zhang, T., Li, D.C., Ma, X.F., Ren, F., Zhao, W.J.: Evaluation Index System and Development Sustainability of Nongan County Ecology Demonstration Zone in Jilin Province. Journal of Jilin University (Earth Science Edition) 36, 95-99 (2006) (in Chinese)

6. Chen, H., Kang, M.Y., Zhao, Y.L., Liang, X.Y., Fan, Y.D.: Degree and Its Application of Sustainable Development of Ecological Demonstration Areas. Bulletin of Soil and Water Conservation 23(4), 61-65 (2003) (in Chinese)

7. Saaty, T.L.: Theory and applications of the analytic network process. RWS Publications, Pittsburgh (2005)

8. Li, Z.W., Zeng, G.M., Zhang, H., Yang, B., Jiao, S.: The integrated eco-environment assessment of the red soil hilly region based on GIS-A case study in Changsha City, China. Ecological modelling 202, 540-546 (2007) 